\title{
Characteristics and Activities of Women with Socio-Economic Prone in the Pattingaloang Baru Village, Ujung Tanah District, Makassar City
}

\author{
Ibnu Hajar', Andi Agustang 2 , Arlin Adam ${ }^{3}$ \\ ${ }^{1}$ Universitas Islam Alauddin Makassar, Indonesia \\ ${ }^{2}$ Universitas Negri Makassar, Indonesia \\ ${ }^{3}$ Universitas Pejuang Republik Indonesia, Indonesia \\ ibnuhajar@uin-alauddin.ac.id, Andiagust63@gmail.com,Arlin.adam73@gmail.com
}

\section{Abstract}

The role of women in the family is very influential in welfare as the smallest unit in society. Women must play an active role in changing their own circumstances, especially women who are vulnerable to socioeconomic conditions, the position of women in a modern perspective no longer sees women as mere objects, but rather their position as subjects who play a role in economic life, therefore this study aims to determine their activities and characteristics. Socioeconomic vulnerable women. This research is a form of social research that uses a qualitative descriptive format that aims to describe, summarize various conditions, as situations or various social reality phenomena that exist in society which are the object of research, and attempt to draw that reality to the surface as a characteristic, character, and nature., sign model, or a description of certain conditions, situations, or phenomena. Women who are socially and economically vulnerable in Darmaguna village are relatively aged 20-40 years, have the status of widows, have low education and limited skills, and have a large number of dependents. In fulfilling physiological, economic, emotional, intellectual, and religious needs, it still shows a very low presentation.

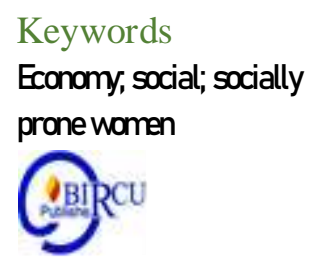

\section{Introduction}

Empowerment refers to the word empowerment, which is an effort to actualize the potential that is already owned by the community, as well as within oneself. In Payne's view (1997: 266), empowerment is essentially aimed at: To help clients gain power of decision and action over their own lives by reducing the effect of social or personal blocks to exercising existing power, by increasing capacity and self-confidence to use power and by transferring power from the environment to clients (helping clients gain the power to make decisions and determine the actions they will take related to themselves, including reducing the effects of personal and social barriers to action. This is done through increasing abilities and the confidence to use the power he has.

Then empowerment can also be interpreted as one of the solutions for those who experience powerlessness so that they participate in feeling the results of development that they have not fully felt, this is because development is actually considered as something that weakens the position of vulnerable communities. (Adiwijaya et al, 2018)

Acording Heathfield in Abida, et al. (2020). explains that Empowerment plays an important role in employee satisfaction thereby increasing their performance in the organization. Empowerment is also defined as a process that allows and gives authority to 
individuals to think, behave, take action and make decisions and control work independently. It is the feeling of self control of one's own destiny.

Community empowerment as an application of government programs requires full enthusiasm from the community itself so that they will make every effort to improve the quality of their human resources in a total and continuous manner. Many efforts have indeed been carried out by the government, one of which is by providing assistance which is directly channeled to remote villages to support village development and the development of local potentials that are undoubtedly empowered. (Mawardi et al, 2019)

In the development literature, the concept of empowerment has even a broader perspective. Pearse and Stiefel (1979), for example, say that respecting diversity, local distinctiveness, deconcentrating power, and increasing independence are forms of participatory empowerment (AMW Pranarka and Vidhyandika Moerjarto, 1996: 63). In addition, literacy can be interpreted as a source of empowerment related to gender issues. Karl (1995) views women's empowerment as a process of awareness and capacity building for greater participation, greater power and control of decision-making, and transformational action in order to produce greater equality between women and men. Sen and Grown (1987) and Vargas (1991), furthermore views that women's organizations must strengthen their organizational capacity and crystallize a vision and perspective that is able to change their current situation. This effort is important as a reality for women - especially women who are vulnerable to socioeconomic conditions, because the living conditions experienced are not merely a natural process, but a process of denial of social, economic and political empowerment. In reality, they seem to have little strength but are able to survive, overthrow and sometimes transform their living conditions. So, the power exists, it just needs to be shown and developed. This effort is important as a reality for women - especially women who are vulnerable to socioeconomic conditions, because the living conditions experienced are not merely a natural process, but a process of denial of social, economic and political empowerment. In reality, they seem to have little strength but are able to survive, overthrow and sometimes transform their living conditions. So, the power exists, it just needs to be shown and developed. This effort is important as a reality for women - especially women who are vulnerable to socioeconomic conditions, because the living conditions experienced are not merely a natural process, but a process of denial of social, economic and political empowerment. In reality, they seem to have little strength but are able to survive, overthrow and sometimes transform their living conditions. So, the power exists, it just needs to be shown and developed. overthrow and sometimes transform their living conditions. So, the power exists, it just needs to be shown and developed. overthrow and sometimes transform their living conditions. So, the power exists, it just needs to be shown and developed.

Related to that, in family life which is the smallest social unit in society, the state recognizes de jure, a father as a family (State Guidelines, 2000). However, de facto, often a mother has to be the head of the household because her husband leaves her because of death, divorce, separation or work in another city, or other reasons (Prijono, 1996: 214). In these circumstances, a mother plays a role and is responsible for problems in and outside the home. Sen and Grown (in Walter, 2001) found in their studies that the decade 1975 - 1985, which the United Nations had declared a decade for the advancement of women, showed a worsening situation for women in Southern countries. Although the workload has increased, there has been a decline in their access to economic resources, education and health status. The majority of women who live without husbands (read: women who are socially and economically vulnerable), either because of their own wishes or because their husbands leave them because 
of divorce or divorce, or because of environmental pressures, experience a process of resignation and extra impoverishment.

Thus it will further sharpen the problem when the times and technology are increasingly advanced for the sake of survival, have an impact on the fulfillment of basic needs which also increase both in quality and quantity so that socio-economic and community vulnerable women are required to meet their basic needs. Fulfillment of basic needs is the basic human needs that can support for proper and balanced development, such as clothing, shelter, food, health and education. Endah Triwijati (1996) states that the fulfillment of women's basic needs needs to be fulfilled so that they can survive to support their families. For example, the problem of increasing food, improving housing, increasing income, employment, basic education, and health services.

The family as the smallest social unit is seen as the basis of mankind, therefore family is a fundamental element of community life (Syarif Muhidin, 1997: 46). So that its existence should be observed together so that it is not trapped in a malfunction which results in detrimental to the existence of the family because of the basic needs of the family itself.

\section{Research Methods}

\subsection{Types of Research}

The method used in this research is a qualitative descriptive method, which is a research method that aims to provide a description of a community or a particular group of people or a description of a symptom or a relationship between two or more symptoms (Atherton \& Klemmack, in Irawan Soehartono, 2000: 35). The characteristics of descriptive research according to Jusman Iskandar and Carolina Nitimihardjo (1411 H.: 120) are:

1. Pay more attention to getting a representative population sample in the study.

2. More precise data collection techniques or procedures

3. The problem statement is clearer

Understanding the descriptive method itself according to Moh. Nazir (1988: 63) is a method in examining the status of a group of people, an object, a set of conditions, a system of thought conditions or a class of participation in the present. The purpose of this descriptive study is to make a systematic, factual and accurate description of the picture or painting regarding the facts and the relationship between the phenomena being investigated.

\section{Discussion}

\subsection{Respondent Characteristics}

\section{Respondent Characteristics Based on Domicile}

Table 1. Recapitulation of Respondents Based on Domicile in Rw Pattingaloang Baru Village, Ujung Tanah District, Makassar City in 2020

\begin{tabular}{|c|c|c|c|}
\hline No. & RW & Total & \% \\
\hline 1. & 01 & 12 & 46.14 \\
2. & 02 & 5 & 19.24 \\
3. & 03 & 9 & 34.62 \\
\hline \multicolumn{2}{|c|}{ Total } & $\mathbf{2 6}$ & $\mathbf{1 0 0 . 0 0}$ \\
\hline
\end{tabular}

Source: Primary data for 2020 
Based on the data in the table above, it can be seen that the majority of women who are vulnerable to socioeconomic are in RW 01 with 12 people or $46.14 \%$, then in RW 03 of $34.62 \%$ or 9 people and RW 02 of 5 people or 19.24\%, all of whom were widows.

\section{Characteristics of Factors Causing Respondents to Become Widows}

Table 2. Factors Causing Respondents to Become Widows

\begin{tabular}{|c|c|c|c|}
\hline No. & Causative Factor & Total & \% \\
\hline 1 & death divorce & 8 & 30.77 \\
2 & divorced & 18 & 69.23 \\
\hline \multicolumn{2}{|c|}{ Total } & $\mathbf{2 6}$ & $\mathbf{1 0 0 . 0 0}$ \\
\hline
\end{tabular}

Source: Primary data for 2020

\section{Characteristics of Respondents by Age Group}

Table 3. Characteristics of Respondents by Age Group.

\begin{tabular}{|c|c|c|c|}
\hline No. & Age (Years) & Total & \% \\
\hline 1. & $20-25$ & 1 & 3.85 \\
2. & $26-30$ & 6 & 23.08 \\
3. & $31-35$ & 3 & 11.54 \\
4. & $36-40$ & 14 & 53.83 \\
5. & $41-50$ & 2 & 7,70 \\
\hline \multicolumn{2}{|c|}{ Total } & $\mathbf{2 6}$ & $\mathbf{1 0 0 . 0 0}$ \\
\hline
\end{tabular}

Source: Primary data for 2020

The data in the table above shows that the age of the majority of respondents is between 36 and 40 years, which is $53.83 \%$ of a person in the mature and independent age category. This should have an effect on respondents in carrying out activities to increase their business in meeting family needs. However, the educational factor also dominates in one's activities in meeting family needs.

\subsection{Respondents' Activities in Meeting Family Needs}

Someone performs activities based on the urge to meet a perceived need such as economic needs, physiological needs, emotional needs, intellectual needs, religious needs and social needs.

\section{Economic Needs}

a) Profession

Table 4. The respondents' limited skills are reflected in the respondent's ability to access jobs

\begin{tabular}{|c|c|c|c|}
\hline No & Type of Work & Total & \% \\
\hline 1. & Farm workers & 21 & 80.76 \\
2. & Factory workers & 4 & 15.38 \\
3. & Selling cakes & 1 & 3.84 \\
\hline \multicolumn{2}{|c|}{ Total } & $\mathbf{2 3}$ & $\mathbf{1 0 0 . 0 0}$ \\
\hline
\end{tabular}

Source: Primary data for 2020

Based on the data above, it can be said that the largest type of work of the respondents is farm labor, namely $80.76 \%$. As farm laborers, respondents also do not have a side income that can support the basic income above so that they are able to support life and meet family needs. 
This is reflected in the respondent's answer to the question asking about the respondent's side job. It turned out that all respondents stated that they did not have a side job.

Meanwhile, for the needs of their children who are still in school, they hope for assistance from a foundation. This inability is clearly related to low education and limited skills of respondents so that they are unable to access decent work to fulfill family needs.

b).Income

As the explanation above, low education and limited skills affect access to work which of course affects income.

Table 5. Respondents' income in a month can be seen in the table below:

\begin{tabular}{|c|c|c|c|}
\hline No & Income / Month (Rp) & Total & \% \\
\hline 1. & I $<500,000.00$ & 23 & 88.46 \\
2. & $500,000.00-800,000.00$ & 3 & 11.54 \\
\hline \multicolumn{2}{|c|}{ Total } & $\mathbf{2 6}$ & $\mathbf{1 0 0 . 0 0}$ \\
\hline
\end{tabular}

Source: Primary data for 2020

Based on the table above, it can be seen that the respondent's income is $<\mathrm{Rp}$. 500,000.00 as much as $88.46 \%$, meanwhile. Things that clarify the reality of respondents in meeting even the simplest family needs, such as the problem of increasing food, meeting health needs, the need for adequate housing and meeting the needs for clothing, are difficult to fulfill.

c) Level of fulfillment of daily needs

Related to the income mentioned above is the level of fulfillment of the daily needs of the family which can be seen in the table below:

Table 6. Respondents' Answers to the Daily Needs of Family Fulfillment Level

\begin{tabular}{|c|c|c|c|}
\hline No & Answer Category & Total & \% \\
\hline 1. & Sometimes it is fulfilled & 3 & 11.54 \\
2. & Not fulfilled & 23 & 88.46 \\
\hline \multicolumn{2}{|c|}{ Total } & $\mathbf{2 6}$ & $\mathbf{1 0 0 . 0 0}$ \\
\hline
\end{tabular}

Source: Primary data for 2020

The table shows that the income received cannot meet the daily needs of the family with the majority of respondents as many as 23 people or $88.46 \%$. This does not only threaten the existence of the respondents, but more than that their children who are raised and educated by single parents with all their limitations.

d) Efforts to overcome the lack of necessities of daily life

As human respondents do something in an effort to overcome the shortage of family needs for daily life so that they continue to survey. 
Table 7. Following are the answers of respondents to questions about the efforts being made to overcome the lack of daily family needs:

\begin{tabular}{|l|l|r|r|}
\hline No & \multicolumn{1}{|c|}{ Answer Category } & \multicolumn{1}{|c|}{ Total } & \multicolumn{1}{c|}{$\%$} \\
\hline 1. & Borrow from close family / household & 5 & 19.24 \\
2. & Wish you mercy & 2 & 7,70 \\
3. & Hoping for help from the Al-Furgon & 19 & 73.06 \\
& Foundation & & \\
\hline \multicolumn{1}{|c|}{ Total } & $\mathbf{2 6}$ & $\mathbf{1 0 0 . 0 0}$ \\
\hline
\end{tabular}

Source: Primary data for 2020

An illustration of an expectation can be seen in table 12, where $73.06 \%$ of respondents from a foundation provide compensation to them, especially for the needs of their children who are in the category of elementary school age. It is ironic for human dignity when faced with two choices: to be a asker or a giver. But it is understandable by looking at the reality of the respondents who are of course faced with these two choices, but how the adversity is overcome so that they do not continue to be marginalized people.

This burden becomes heavier when no family member helps ease the burden that must be borne by the respondent in supporting his family. In this regard, there are three strong reasons: (1) more than $80 \%$ of the respondents' children are still under five and elementary school age (aged 6-12 years); (2) the low level of education of the respondent's family members and their limited skills so that it is difficult to access work, except for being a seasonal farm laborer; and (3) agricultural land in the village is very limited and infertile which affects the wages of the farm workers themselves. Thus, it becomes a cycle of poverty that has no end or in Oscar Lewis's terms as a culture of poverty.

\section{Physiological Needs}

a) Food needs

Physiological needs are one of the basic needs that must be met in order to support the survival of the respondent's family. Related to that, the respondent's answer to the question of family meal frequency from the 26 respondents gave the same answer, namely 2 times a day with a simple menu as the respondent's answer to the question about the menu served by the respondent (26 respondents stated the same thing). This illustrates the limitations of respondents in serving menus that meet nutritional and protein standards that must be consumed by all family members. The issue of frequency of eating only twice a day is a common habit in the Sabbamparu Village.

However, the insufficient nutritional value and protein in food and the frequency of eating only twice a day will affect the development and growth of bones and brains of family members, especially those who are still in their growing age. In terms of the frequency of rice needs in a month, it can be seen that the respondents' answers correspond to the number of dependents of each.

Table 8. The respondents' answers correspond to the number of dependents of each.

\begin{tabular}{|c|c|c|c|}
\hline No & Answer Category & Total & \% \\
\hline 1. & $>40 \mathrm{Kg}$ & 7 & 28.76 \\
\hline 2. & $20-40 \mathrm{Kg}$ & 10 & 39.46 \\
\hline 3. & $<20 \mathrm{Kg}$ & 8 & 31.78 \\
\hline Total & $\mathbf{2 6}$ & $\mathbf{1 0 0 . 0 0}$ & 31.78 \\
\hline
\end{tabular}

Source: Primary data for 2020 


\section{b) Clothing Needs}

The need for clothing is important for human life because the main function of clothing is to cover human genitals. Without clothes / clothing, humans can be said to be not human because they have no more shame than animals that are not endowed with a healthy sense by God.

Respondents as to the question of meeting the needs for clothing in a year, the answers given by all respondents were only to buy clothes once a year and that too on 'Idul Fitri. This is because the respondent's income is far from the average UMR in Cirebon Regency. Likewise, in fulfilling the needs of their children's school clothes for respondents whose children are still in school. All respondents stated that they sometimes buy it in the sense that when the school clothes are no longer suitable to be worn, such as torn and other things.

From the need for clothing to the question of how to get it, it turned out that the respondent gave the answer to getting help from the Al Furqon Foundation, a non-profit foundation from Jakarta that deals with orphans. This shows how the respondent really depends his life on other people to fulfill his clothing needs.

c) Board Needs

To find out the ownership status of the respondent's house, it can be seen in the table below:

Table 9. Respondent Home Ownership Status

\begin{tabular}{|c|c|c|c|}
\hline No & Answer Category & Total & $\%$ \\
\hline 1. & One's own & 17 & 65.38 \\
\hline 2. & Hitchhiking parents & 9 & 34.62 \\
\hline \multicolumn{2}{|r|}{ Total } & 26 & 100.00 \\
\hline
\end{tabular}

Source: Primary data for 2020

It turns out that most of the respondents already have their own house, although it is inadequate and it meets the standard of livable and adequate housing for all family members. Below can be seen the respondent's answer regarding the adequacy of the house to be occupied by all family members:

Table 10. Respondents' Answers to the Existence of Houses for All Family Members

\begin{tabular}{|c|c|c|c|}
\hline No & Answer Category & Total & \% \\
\hline 1. & Adequate & 4 & 15.40 \\
2. & Inadequate & 22 & 84.60 \\
\hline \multicolumn{2}{|c|}{ Total } & $\mathbf{2 6}$ & $\mathbf{1 0 0 . 0 0}$ \\
\hline
\end{tabular}

Source: Primary data for 2020

The data in the table above shows that as many as $84.60 \%$ of respondents stated that the house they occupied was inadequate, and $15.40 \%$ or 4 respondents stated that it was adequate. This is in accordance with the level of the respondent's ability to meet the needs seen from the activities that the respondent has been doing so far. The following can also be seen about the respondent's answer about whether the house is always repaired if there is damage as in the table below: 
Table 11. The Intensity of Home Repair If There Is Damage

\begin{tabular}{|c|c|c|c|}
\hline No & Answer Category & Total & \% \\
\hline 1. & Sometimes & 4 & 19.24 \\
2. & Never & 21 & 80.76 \\
\hline \multicolumn{2}{|c|}{ Total } & $\mathbf{2 6}$ & $\mathbf{1 0 0 . 0 0}$ \\
\hline
\end{tabular}

Source: Primary data for 2020

From the answers given, 21 respondents or $80.76 \%$ answered that it was never repaired and $19.24 \%$ answered that sometimes it depends on the level of damage. If the house is really damaged, then it will be repaired just what it is or in other terms it is done by patchwork.

d) Health Needs

Physiological needs that are no less important are health needs. To find out the place where the respondent brings their family when they are sick, it can be seen in the following table:

Table 12. Respondent's Level of Giving Praise to Family Member Achievement

\begin{tabular}{|c|c|c|c|}
\hline No & Answer Category & Total & \% \\
\hline 1. & Sometimes & 22 & 84.60 \\
2. & Never & 4 & 15.40 \\
\hline \multicolumn{2}{|c|}{ Total } & $\mathbf{2 6}$ & $\mathbf{1 0 0 . 0 0}$ \\
\hline
\end{tabular}

Source: Primary data for 2020

The table above shows that the level of praise from respondents to family members who excel tends to be occasional, namely $84.60 \%$ or 22 respondents. This happens because respondents do not pay much attention to children's learning activities, both at school and at home. Sometimes respondents give praise when they know, but not if they don't know that their child is doing well. And there are 4 respondents or $15.40 \%$ who never pay attention to their children's learning achievement. This does not mean that the respondent does not want to pay attention to the child's achievement, but the living conditions compel the respondent to concentrate on activities that are not able to raise the income level so that the family's needs can be fulfilled properly and fairly. Likewise in terms of respondent attention to interests, talents.

There are many limitations of respondents in meeting these emotional needs so that respondents never know the potential of family members. This lack of attention is more due to the activity factor of respondents who do not recognize rest in their business as the backbone of the family: as a mother as well as a father for their children.

\section{Intellectual Needs}

Intellectual needs are important in child development. Meeting these intellectual needs can be seen in the following table:

Table 13. Respondents' Level of Attention to Children's School Development

\begin{tabular}{|c|c|c|c|}
\hline No & Answer Category & Total & \% \\
\hline 1. & Sometimes & 24 & 92.30 \\
2. & Never & 2 & 7,70 \\
\hline \multicolumn{2}{|c|}{ Total } & $\mathbf{2 6}$ & $\mathbf{1 0 0 . 0 0}$ \\
\hline
\end{tabular}

Source: Primary data for 2020 
As in fulfilling emotional needs, in terms of fulfilling intellectual needs in the table above, 24 respondents or $92.30 \%$ sometimes follow children's development through children's learning outcomes that can be seen in report cards. This means that the respondent follows these developments when the report card is presented by his child, the respondent will see and pay attention and provide advice for the progress of their child in school. Meanwhile, 2 respondents or $7.70 \%$ stated that they had never followed the progress of children's achievement through school report cards due to the respondents' ignorance of the importance of parental attention to children's development. To find out the extent to which respondents provide study guidance to their children who are still in school, the following table:

Table 14. The intensity of tutoring provided by respondents to their children who are still in school

\begin{tabular}{|l|l|r|r|}
\hline No & \multicolumn{1}{|c|}{ Answer Category } & Total & \multicolumn{1}{c|}{$\%$} \\
\hline 1. & Sometimes & 24 & 92.30 \\
2. & Never & 2 & 7,70 \\
\hline \multicolumn{2}{|c|}{ Total } & $\mathbf{2 6}$ & $\mathbf{1 0 0 . 0 0}$ \\
\hline
\end{tabular}

Source: Primary data for 2020

Similar to the answers given above, the respondents who gave answers sometimes were $92.301 \%$ or 24 respondents. This means that if the child has difficulties in doing his homework, the respondent only provides guidance and teaches the child things that are not understood. This is due to limitations in the respondents, most of whom only graduated from elementary school, and this is also if the respondent is not exhausted after a full day of work. And 2 respondents or $7.70 \%$ gave the answer that they never gave guidance to their children. This does not mean that the respondent allows their children to study on their own, but rather asks their siblings to help the younger siblings. The lack of attention is due to the respondents' low occupation or knowledge.

In terms of obtaining information, the respondent gave an answer that the information was obtained only from recitation, although it did not rule out the possibility that the respondent's family member would get it by watching the neighbor's television.

\section{Religious Needs}

Spiritual needs or religious needs become very important when humans crave harmony in their life journey. Religion is the main foundation of humans in doing anything in their life, without religion what happens is the law of the jungle and the brutality of life. Religion provides a fortress for people to be polite and respect each other as a person respects himself.

In this regard, the fulfillment of religious needs is very important for anyone, especially women who are vulnerable to socio-economics so that their families do not get trapped in the glitter of temporary world life. In the daily activities carried out by respondents, respondents are very disciplined in instilling these religious values in their families. From the answers to the question about whether the whole family always practices worship, all respondents answered "yes". This means that as the head of the family, the respondent feels responsible for mentally preparing his family not to get lost. Whatever the current situation, as long as not selling and neglecting worship is a joy for the respondent. Likewise in carrying out worship, respondents sometimes carry out congregation with the whole family, at least for maghrib prayer. To find out where the respondent and his family worship daily can be seen in the table below: 
Table 15. Place of Respondent and Family in Carrying out Daily Worship

\begin{tabular}{|c|c|c|c|}
\hline No & Answer Category & Total & \% \\
\hline 1. & Mosque / Mushola & 5 & 19.24 \\
2. & House & 21 & 80.76 \\
\hline \multicolumn{2}{|c|}{ Total } & $\mathbf{2 6}$ & $\mathbf{1 0 0 . 0 0}$ \\
\hline
\end{tabular}

Source: Primary data for 2020

The data in the table shows that the majority of respondents and their families perform worship at home, amounting to $80.76 \%$. This is due to the absence of time to worship specifically at the mosque or prayer room. During the daytime (midday and Asr prayer times) it is more often done at work. And the evening is usually done with other families at home. For those who carry out worship in mosques or prayer rooms, it is $19.24 \%$, because the place is close to the mosque or prayer room so there is no reason not to congregate at the mosque or in the mosque.

Respondents as described above are very strict in instilling religious values directly at home and also require their family members to continue to recite the Koran at the nearest mosque or prayer room so that the respondent's family members also receive religious education through a religious teacher.

\section{Social Needs}

Social needs, which are basic human needs in socializing with the surrounding community, are also important to be fulfilled so that as members of the community they are not isolated and become the topic of conversation of other communities. However, from the questions posed to respondents about their participation, even their family members in the organizations in the environment where the respondent is located, not even one was followed. This is due to the respondent's ignorance of the existing activities, the respondent's busy activities that are not measured by the time and less opportunity given to respondents to express themselves because they are considered as women even though they are the head of the household.

However, this is not a measure of acceptance or not in society. Respondents in other respects are quite communicative and always get attention from their neighbors when their neighbors have excess fortune, for example. There is a lot of assistance or assistance that has been provided by the neighbors or the environment where the respondent is domiciled so far which can be used as justification that the respondent and his family can be accepted by the surrounding environment. The following is the form of assistance / assistance provided by neighbors / neighborhoods to respondents as shown in the table below:

Table 16. Respondents' Answers to Assistance Received from Neighbors / Their Environment

\begin{tabular}{|c|c|c|c|}
\hline No & Type Of Assistance & Total & \% \\
\hline 1. & Goods & 21 & 80.76 \\
2. & Suggestion & 5 & 19.24 \\
\hline \multicolumn{2}{|c|}{ Total } & $\mathbf{2 6}$ & $\mathbf{1 0 0 . 0 0}$ \\
\hline
\end{tabular}

Source: Primary data for 2020

Based on the table above, it can be said that the level of social environmental awareness of the respondents is very high. Respondents who gave answer 21 for goods received in the form of clothing and food needs. For this type of assistance, advice is in the form of reinforcement advice to respondents not to slip into temporary temptations that will harm the respondent himself. This does not mean that the 5 respondents did not receive assistance / 
assistance from their neighbors in the form of goods, but only in terms of the intensity of the form of assistance / assistance received, considering that the 5 respondents were still young (25-30 years old).

\section{Conclusion}

Humans are basically dignified so that as a reasonable human being will carry out their activities to keep on surveying. For this reason, no matter how small the human potential is, if it is empowered it will become an enabling source for implementing and accessing development programs.

Based on research conducted on 26 respondents, it is known that women who are prone to socio-economics in Damarguna Village in fulfilling family needs can be concluded as follows.

1. Characteristics

The characteristics of women who are vulnerable to socio-economic conditions in Damarguna Village are as follows:

a. Relatively young age between 20-40 years.

b. The status of widows, with the majority of widows being divorced.

c. Low education and limited skills.

d. Lots of dependents.

2. Respondents' activities in fulfilling family needs

The activities of women who are vulnerable to socioeconomic conditions in fulfilling family needs are as follows:

a. Economic needs

The low income level of the respondents is much lower than the UMR Cirebon Regency of Rp. 390,000.00 so that it could not meet the economic needs of the family so that the respondents tried to solve it by hoping for help from other parties.

b. Physiological needs

In fulfilling physiological needs, it appears that the respondents are not able to meet family needs properly. So that it can result in a culture of poverty, namely poverty that is passed down from generation to generation if there is no solution. However, the frequency of fulfilling rice in a month is still in accordance with the size of the number of dependents of each respondent.

In fulfilling the clothing needs, respondents are only able to buy once a year. Likewise, their children who are still in school depend more on a foundation. Meanwhile, for housing needs, respondents have their own house, although it is not sufficient. This can also be seen in the efforts to repair houses if there is damage, respondents sometimes repair them and this is also very urgent.

In terms of meeting health needs, respondents put this need into the order that was not taken into account because in obtaining medicines the respondents prefer to buy at the shop rather than going to the puskesmas, even though there is a significant risk of buying drugs carelessly at the stall.

c. Emotional needs

The attention of respondents to their families in research conducted by researchers shows an answer that sometimes gives praise and attention ranks first. This does not mean that the respondent is not paying attention, but rather that the respondent is busy in their activities and considers that praise for them is not important enough to be given to the family which is just lip service. 


\section{d. Intellectual needs}

In fulfilling intellectual needs, respondents are less able to provide study guidance to their children and more are left to other family members (older siblings). This is done considering the low level of education of respondents so that they cannot follow the learning process of children in schools that tend to be advanced. Likewise, in providing tutoring at home to their children who are still in school, the majority of respondents stated that they sometimes provide guidance and this is because their child's report cards are presented.

e. Religious needs

Religion becomes everything for respondents when everything is difficult to fulfill. In fulfilling these religious needs, respondents are very concerned because religion is the basis for navigating life. This is done to fortify family members so that they do not fall into things that destroy morals because of the poverty they experience. Likewise, the majority of respondents and family members carry out their prayers at home because of the respondent's busy activities that do not know the time.

f. Social Needs

Respondents can perform this function because of the ability of respondents to socialize conducive social interaction between family members and the existing social environment and vice versa. This is proven by the concern of the surrounding community for the respondent and his family.

The legal remedy of a Notary as a proxy for registration and registration of business entities through the Business Entity Administration System (SABU) which can be taken by a Notary is refusing to sign a power of attorney. This has the potential for an act against the law and is not regulated in the Law on Notary Position (UUJN) and the potential for a lawsuit to occur before the court.

\section{References}

Abida, et al. (2020). Empowerment and Enrichment Principles in the Philosophy of Pucuk Rebung Motives of Karawang Gayo. Budapest International Research and Critics Institute-Journal (BIRCI-Journal). P. 3912-3922

Adiwijaya, S., et al. (2018). Empowerment Pattern for Thalasemi Patients in Dr. Soetomo Hospital Surabaya (Study of the Association of Parents with Thalassemia Indonesia, Surabaya). Budapest International Research and Critics Institute-Journal (BIRCIJournal. P. 289-298.

Andre Bayo Ala (ed). (1996). Poverty and the Strategy to Combat Poverty. Yogyakarta: Liberty.

Central Bureau of Statistics. (1992). Results of the 1990 Population Census. Jakarta: BPS.

Ministry of Social Affairs of the Republic of Indonesia. 1996. Basic Patterns of Social Welfare Development. Jakarta: Directorate General of Social Welfare Development.

Dewa Ketut Sukardi. (1984). Introduction to Counseling Theory. Jakarta: Ghalia Indonesia.

Dubois, Brenda and KK Miley. (1992). Social Work an Empowering Profession. USA: Allyn \& Bacon inc.

Dwi Heru Sukoco. (1993). The Social Work Profession and Its Relief Process. Bandung: Kopma - STKS.

Edi Suharto. (1997). Development, Social Policy \& Social Work: The Spectrum of Thought. Bandung: LSP-STKS.

Emil Salim. (1982). Development Planning and Income Equity. Jakarta: Indayu Foundation. 
Endah Triwijati. (1996). "Transparent Women's NGO: Alternative Movement for Women's Empowerment". In Mayling Oey-Gardiner, et.al. Indonesian Women: Past and Present. Jakarta: PT Gramedia Pustaka Utama.

State Policy Guidelines (GBHN) 2000-2005. (2000) Jakarta: Sinar Grafika.

Gerungan, WA.(1996). Social Psychology. Bandung: Eresco.

Goode, William J. (1991). Sociology of the Family (translated by Dra. Lailahanoum Hasyim). Jakarta: Earth Literacy.

Holil Soelaiman. (1994). "Families in Rapid Socio-Economic Change and Its Implications for Social Welfare". In the Journal of Social Welfare Research and Development. Jakarta: Ministry of Social Affairs.

Irawan Soehartono. (2000). Social Research Methods: A Research Technique in the Field of Social Welfare and Other Social Sciences. Bandung: PT Remaja Rosda Karya.

Isbandi Rukminto Adi. (2001). Empowerment, Community Development and Community Intervention (Introduction to Practical Thinking and Approaches). Jakarta: Publishing Institute, Faculty of Economics, UI.

Jusman Iskandar and Carolina Nitimihardjo [ed]. $1411 \mathrm{H}$. Introduction to Social Work Research. Bandung: Kopma with An-Naba DKM Al-Ihsan - STKS.

Regional Office of the Ministry of Social Affairs, Prop. West Java. (1999). Limits on the Operational Definition of PMKS and PSKS. Bandung: West Java Depsos Regional Office.

Mawardi et al. (2019). Agenda Empowerment of People in Tarmizi Taher Point of View. Budapest International Research and Critics Institute-Journal (BIRCI-Journal). P. 443450

Moh. Nasir. (1988). Research Methods. Jakarta: Ghalia Indonesia.

Morales, Armando and Sheafor. (1983). Social Work a Profession of Many Faces. Boston: Allyn and Bacon Inc.

Nani Sudarsono. (1987). Speech Association of the Minister of Social Affairs of the Republic of Indonesia. Jakarta: Ministry of Social Affairs RI.

Onny S. Prijono. (1996). "Empowering Women as Equal Partners for Men". In Onny S. Prijono and AMW Pranarka [ed]. Empowerment: Concept, Policy and Implementation. Jakarta: CSIS.

Pudjiwati Sajogyo. (1985). The Role of Women in Village Community Development. Jakarta: Rajawali.

Robert MZ Lawang. (1985). Introduction to Sociology. Jakarta: Gift.

Singgih D. Gunarsa. (1992). Introduction to Psychology. Jakarta: Mutiara Sumber Widya.

Suharsimi Arikunto. (1992). Research Procedure. Jakarta: Bina Literacy.

Syarif Muhidin. (1997). Introduction to Social Welfare. Bandung: Your partner.

Soerjono Soekanto. (1990). Sociology of the Family Concerning Family, Youth and Children. Jakarta: Rineka Cipta.

Walter, Victoria. (2001). "Women and the Elimination of Poverty". In Izzedin Bakhit, at.al. Fighting the Roots of Poverty (interpreted by: Frederik Ruma). Jakarta: Yagoma - PGI. 